\title{
BIMBINGAN DAN KONSELING ISLAM PADA SISWA BERPERILAKU KECENDERUNGAN NARSIS DI KELAS XI MAN 2 PONTIANAK
}

\author{
Hesty Nurrahmi \\ Elvya Rizki Oktaviani \\ Fakultas Ushuluddin, Adab dan Dakwah (FUAD) \\ Institut Agama Islam Negeri (IAIN) Pontianak \\ Email: esty4murni@gmail.com
}

\begin{abstract}
:
The purpose of this study was to reveal the guidance of Islamic counseling on the behavior of students who tend to be narcissistic. This study uses action research methods. The process of conducting research was carried out with the following stages: planning, action, reflection (observation) and evaluation. The results of the study showed: (1) The right Islamic Counseling Guidance Service in dealing with students behaving students was by using the type of group guidance and counseling; (2) The results of the application of this model appear in the data that: based on the data obtained when viewed from the meeting before the action until after the 6th and 7 th meetings, there was a decrease in the percentage of narcissistic behavior by $39.22 \%$. The percentage of narcissistic behavior of $72.12 \%$ decreased to $32.90 \%$.

(Tujuan penelitian ini adalah untuk mengungkap bimbingan konseling Islam terhadap perilaku siswa yang cenderung narsis. Penelitian ini menggunakan metode penelitian tindakan. Proses pelaksanaan penelitian dilakukan dengan tahapan sebagai berikut: perencanaan, tindakan, refleksi (pengamatan) dan evaluasi. Hasil penelitian menunjukkan: (1) Layanan Bimbingan Konseling Islam yang tepat dalam menangani siswa berperilaku siswa adalah dengan menggunakan jenis bimbingan dan konseling kelompok; (2) Hasil dari penerapan model ini tampak pada data bahwa: berdasarkan data yang diperoleh jika dilihat dari pertemuan sebelum tindakan sampai kepada setelah pertemuan ke 6 dan 7, terjadi penurunan persentase perilaku narsis sebesar 39,22\%. Persentase perilaku narsis sebesar $72,12 \%$ menurun menjadi $32,90 \%$ ).
\end{abstract}

Kata Kunci: Bimbingan Konseling Islam, Perilaku Narsis

\section{PENDAHULUAN}

Manusia diciptakan oleh Allah SWT dalam keadaan yang terbaik, sempurna, termulia dibandingkan dengan makhluk lainnya. Manusia di hadapan Allah Ta'ala bukan seperti makhluk lain, akan tetapi sebagai makhluk yang memiliki kesempurnaan. Sebagaimana firman Allah SWT dalam surat At-Tiin [95]: 4 sebagai berikut:

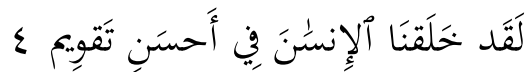

"Sesungguhnya Kami telah menciptakan manusia dalam bentuk yang sebaikbaiknya".

Ayat di atas sangat jelas mengatakan bahwa manusia diciptakan Allah Swt sebagai makhluk dalam bentuk yang sebaik-baiknya. Kata "sebaik-baiknya" dapat diartikan sebagai tiada yang lebih 
baik lagi. Maka dari itu manusia dikatakan makhluk sempurna di antara makhluk yang lain.

Manusia memiliki sikap atau tingkah laku. Setiap tingkah laku manusia merupakan cerminan dari beberapa kebutuhan ${ }^{1}$. Apabila dalam pemenuhan kebutuhan tersebut dilakukan secara berlebihan atau terkesan memaksa maka akan menimbulkan penyimpangan - penyimpangan psikologis. Adapun salah satu penyimpangan psikologis tersebut adalah Narsis yang merupakan gangguan kepribadian. Manusia pada usia 12 sampai 18 tahun sedang dalam pertumbuhan yang mengalami masa remaja. Masa remaja termasuk masa yang sangat menentukan karena masa ini manusia mengalami banyak perubahan pada psikis maupun fisiknya. Dalam proses perubahan psikis dan fisik pada masa remaja, teknologi canggih ikut berpengaruh. Teknologi canggih dapat memberikan pengaruh positif dan negatif. Pengaruh positif dari teknologi canggih salah satunya adalah remaja dapat mengikuti segala hal yang berhubungan dengan perkembangan zaman. Adapun pengaruh negatif dari teknologi canggih dalam proses perubahan psikis remaja adalah timbul nya narcissism, yaitu gangguan kepribadian.

\footnotetext{
Kartono, K. 2000. Hygine Mental.
} Bandung: Mandar Maju, hlm. 36.
Tanpa disadari, dengan semakin canggihnya teknologi sekarang ini, ternyata menimbulkan pengaruh terhadap timbulnya narcissism pada seseorang, khususnya remaja. Gangguan kepribadian pada masa remaja bisa terjadi mengingat masa remaja merupakan masa pencarian jati diri, mereka membutuhkan pengakuan dan perhatian dari orang lain dan lingkungan sekitarnya. Pengakuan ini dapat berupa pujian dan sanjungan dari orang lain tentang diri mereka. Pada kelanjutannya perasaan bangga dipuji karena potensi cantik, pintar, ganteng dan sifat lain yang dimilikinya tersebut membuat mereka benci atau tidak suka apabila dikritik. Mereka beranggapan bahwa dirinya adalah orang yang mempunyai kelebihan dibandingkan dengan yang lain. Dan jika ada orang yang lebih dari mereka, maka orang yang memiliki gangguan kepribadian narcissism ini tidak menyukai dan setelah itu akan mengusahakan bagaimana mereka harus lebih unggul dari yang lain. Sebenarnya, setiap orang memiliki kecendrungan narcissism akan tetapi kadarnya berbeda - beda.

Kehidupan di kota-kota berkembang, khususnya Pontianak sangan mempengaruhi pola hidup remaja, dimana mereka sedang berada dalam masa transisi. Perubahan dan aktifitas di kota berkembang seperti Pontianak ini menuntut para 


\section{Al-Hikmah: Jurnal Dakwah, Volume 12, Nomor 1, Tahun 2018 \\ [P. 65-82]}

pelakunya mengikuti geraknya, tanpa terkecuali remaja. Sebagai ibu kota provinsi Kalimantan Barat, Pontianak juga sebagai sebuah kota dengan tingkat moderenitas yang tinggi seolah semakin memberikan peluang bagi munculnya orang yang berperilaku kecenderungan narcissism.

Remaja kadang tidak mengetahui apa dampak dari apa yang mereka lakukan atau kerjakan. Mereka hanya meniru tingkah laku atau gerakan - gerakan yang mereka lihat secara kasat mata dari teman - teman sepermainan, teman - teman sekolah, atau bahkan melalui media sosial seperti, instagram, facebook, tweeter, path dan lain sebagainya serta melalui acara acara yang dimuat di televisi. Sebagaimana diketahui bersama bahwa televisi, instagram, facebook, tweeter, bbm, path merupakan beberapa media dari apa yang dinamakan moderenitas. Dari media sosial tersebut, terbentuklah konsep umum apa yang disebut keren, cantik, ganteng, dan $u p$ to date. Efek moderenitas dari media media ini berpengaruh ke pola pikir dan gaya hidup remaja baik dalam bertingkah laku, cara berpakaian dan berbicara. Keadaan ini menimbulkan istilah "ketinggalan zaman/katrok" bagi orang atau remaja yang tidak bergaya, bertingkah laku dan berpakaian seperti apa yang dituntut oleh moderenitas melalui media media yang telah disebutkan di atas.

Biasanya di luar rumah remaja dan teman - teman sebayanya bergabung dalam kelompok. Ini juga sebuah usaha untuk mencari identitas dan perhatian lingkungan atas existensinya. Tidak bisa disalahkan juga tindakan para remaja, karena tindakan mereka tidak sepenuhnya alami dilakukan karena dari diri mereka sendiri, akan tetapi juga stimulan dari luar, yaitu dengan adanya teknologi yang semakin canggih dengan seiring bertambahnya waktu, seperti adanya photo box di mall - mall, menjamurnya camera professional yang tiap tahun makin canggih yang hanya dengan menyewa beberapa puluh ribu rupiah bisa memakainya, handphone canggih dengan dilengkapi aplikasi - aplikasi camera yang dapat mempercantik atau memperganteng yang berphoto tanpa dibatasi dengan roll film seperti zaman dulu. Belum lagi ditambah dengan adanya media sosial seperti instagram, facebook, tweeter dan path, yang semuanya memanjakan orang, memberikan wadah pameran fisik, dan membuat orang terutama remaja semakin bebas mengeluarkan sisi narcissism-nya. Dengan adanya media sosial tersebut memicu orang ingin berpenampilan sebaik mungkin, dengan tujuan supaya mendapat pujian dari orang lain dan agar dibilang 


\section{Hesty Nurrahmi \\ Elvya Rizki Oktaviani \\ Bimbingan dan Konseling Islam pada Berperilaku Kecenderungan Narsis di Kelas XI MAN 2 Pontianak}

keren, eksis, up to date, serta menganggap dirinya adalah yang paling segalanya dibandingkan lainnya. Sementara orang dengan perilaku yang demikian jauh dari memiliki pengendalian emosi, pengontrolan diri, rasa empati terhadap sesamenya, motivasi, kepekaan sosial atau keterampilan sosial.

Dari uraian - uraian tersebut di atas, penulis ingin mengetahui bagaimana seandainya perilaku ini terjadi pada anak anak sekolah menengah atas yang menjadikan pendidikan agama sebagai identitas kelembagaannya, dan bagaimanakah penanganannya jika hal terebut terjadi pada siswa - siswinya?

MAN 2 Pontianak letak geografisnya sangat strategis, berada di tengah tengah kota, yaitu di Jl. A. Yani No 9 Pontianak. Man 2 Pontianak juga merupakan MAN model, yaitu sebagai sekolah percontohan dari madrasah aliyah negeri lainnya di kota Pontianak. Peneliti sudah melakukan observasi kurang lebih selama 1 bulan, hari aktif sekolah di MAN 2 sehingga mendapatkan indikator tentang kecenderungan perilaku narsisme, adapun yang peneliti temui adalah seperti terdapat siswa yang merasa dirinya sangat penting karena kelebihan yang dimilikinya seperti kepintaran yang ia miliki. Selanjutnya, terdapat siswa selalu ingin dipuji dan diperhatikan. Ada juga siswa kurang peka terhadap kebutuhan temannya yang lain, dalam arti kata egoisentris hanya pendapatnya lah yang harus didengarkan. Terdapat siswa yang sensitif terhadap kritikan, kritikaan yang kecil berarti besar baginya, dan tidak mau disalahkan. Ini peneliti temui pada saat melakukan layanan bimbingan dan konseling kelompok pada siswa kelas XI dan siswanya diambil acak dari masing-masing kelas. Selanjutnya peneliti menemukan ada juga yang agak bangga mempertontonkan anggota tubuhnya, seperti sering photo selfie dan grufie kemudian langsung di upload di media sosial seperti facebook dan instagram. Ini peneliti temui di Media sosial facebook, kebetulan peneliti menjalin pertemanan di facebook dengan siswa kelas XI MAN 2 Pontianak.

Berdasarkan latar belakang masalah di atas, maka rumusan penelitian ini adalah: Apakah materi Bimbingan dan Konseling Islam dalam penanganan siswa berperilaku kecenderungan narsis di kelas XI MAN 2 Pontianak? Bagaimanakah penerapan Bimbingan dan Konseling Islam dalam penanganan siswa berperilaku kecenderungan narsis di kelas XI MAN 2 Pontianak? Bagaimanakah hasil yang didapatkan setelah dilakukannya Bimbingan dan Konseling Islam pada siswa berperilaku kecenderungan narsis di kelas XI MAN 2 Pontianak? 


\section{Al-Hikmah: Jurnal Dakwah, Volume 12, Nomor I, Tahun 2018 \\ [P. 65-82]}

\section{Kajian Teori}

1. Bimbingan dan Konseling Islam

Bimbingan dan Konseling merupakan terjemahan dari "guidance" dan "counseling" dalam bahasa inggris. H.M Umar \& Sartono $^{2}$ mengatakan bahwa secara harfiah istilah "guidance" itu sendiri selain diartikan bimbingan atau bantuan juga diartikan pimpinan, arahan, pedoman, dan petunjuk. Kata guidance berasal dari kata dasar (to) guide, yang artinya menuntun, menjadi petunjuk jalan, mengemudikan ${ }^{3}$.

Kemudian Yusuf Gunawan mengatakan, konseling adalah proses belajar melalui hubungan khusus secara face to face dalam wawancara antara konselor dengan konseli ${ }^{4}$.

Secara teminology, bimbingan telah banyak dikemukakan oleh para ahli, antara lain: Menurut Prayitno bimbingan diartikan sebagai berikut; Bimbingan adalah proses pemberian bantuan yang dilakukan oleh orang yang ahli kepada seorang atau beberapa orang individu, baik anak - anak, remaja, maupun dewasa agar orang yang dibimbing dapat mengembangkan kemampuan dirinya sendiri dan mandiri

2 Sartono, H. U. 2001. Bimbingan dan Penyuluhan. Bandung: CV. Pustaka Setia, hlm. 14.

${ }^{3}$ Sartono, H. U. 2001. Bimbingan..., hlm. 9

4 Gunawan, Y. 2001. Pengantar Bimbingan dan Konseling. Jakarta: Prenhallindo, hlm. 116. dengan memanfaatkan kekuatan individu dan sarana yang ada dan dapat dikembangkan berdasarkan norma norma yang berlaku.

Kemudian dijelaskan lagi oleh Winkel sebagai berikut; Bimbingan yaitu usaha untuk melengkapi individu dengan pengetahuan, pengalaman, dan informasi tentang dirinya sendiri. Bimbingan adalah sejenis pelayanan kepada individu - individu agar mereka dapat menentukan pilihan, menetapkan tujuan dengan tepat, dan menyusun rencana yang realistis, sehingga mereka dapat menyesuaikan diri dengan memuaskan diri dalam lingkungan tempat mereka hidup.

Menurut Djumhur dan Moh. Surya dalam Sulistiya Rini \& Muh. Jauhar ${ }^{5}$ mendefinisikan bimbingan lebih jelas lagi. Bimbingan adalah suatu proses pemberian bantuan yang terus menerus dan sistematis kepada individu dalam memecahkan masalah yang dihadapi, agar tercapai kemampuan untuk memahami dirinya (self understanding), kemampuan untuk menerima dirinya (Self acceptence), kemampuan untuk mengarahkan dirinya (Self ddirection) dan kemampuan untuk merealisasikan dirinya (Self realization)

5 Sulistiya Rini dan Jauhar, Mohammad. 2014. Dasar - dasar Konseling. Jakarta: Prestasi Putaka, hlm. 26. 


\section{Hesty Nurrahmi \\ Elvya Rizki Oktaviani \\ Bimbingan dan Konseling Islam pada Berperilaku Kecenderungan Narsis di Kelas XI MAN 2 Pontianak}

sesuai dengan potensi atau kemampuannya dalam mencapai penyesuaian diri dengan lingkungan, baik keluarga, sekolah dan masyarakat.

Sedangkan konseling, berasal dari kata kerja to counsel yang berarti memberikan nasihat kepada orang lain secara face to face. Kemudian secara terminology, konseling didefinisikan oleh Tolbert yaitu bahwa:

Konseling adalah hubungan pribadi yang dilakukan secara tatap muka antara dua orang dalam mana konselor melalui hubungan itu dengan kemampuan - kempuan khusus yang dimilikinya, menyediakan situasi belajar. Dalam hal ini konseli dibantu untuk memahami diri sendiri, keadaannya sekarang, dan kemungkinan keadaannya masa depan yang dapat ia ciptakan dengan menggunakan potensi yang dimilikinya, demi untuk kesejahteraan pribadi masyarakat. Lebih lanjut, konseli dapat belajar bagaimana memecahkan masalah - masalah dan menemukan kebutuhan - kebutuhan yang akan datang.

Juntika Nurihsan mengemukakan koseling adalah hubungan tatap muka yang bersifat rahasia, penuh dengan sikap penerimaan dan pemberian kesempatan dari konselor kepada klien. Konselor mempergunakan penge- tahuan dan keterampilannya untuk membantu klien mengatasi masalah masalahnya ${ }^{6}$.

Bimbingan dan konseling dapat membantu dan mengubah pola hidup seseorang (klien), mengubah polah hidup yang salah menjadi benar, mengubah pola hidup yang negative menjadi positive. Dengan demikian, klien dapat mengarahkan hidup sesuai dengan tujuannya. Karena tugas seorang pembimbing atau konselor yaitu memberikan arahan yang baik kepada yang dibimbing. Sesuai dengan firman Allah dalam QS: Asy - Syura ayat 52 yang artinya : “....Dan sungguh, engkau benar - benar membimbing (manusia) kepada jalan yang lurus". Bimbingan dan konseling merupakan bagian yang integral dari proses pendidikan dan memiliki kontribusi terhadap keberhasilan proses pendidikan di sekolah.

Adapun kata islam, secara bahasa di ambil dari bahasa Arab, Salima yang berarti selamat sentosa. Dari asal kata itu dibentuk kata Aslama yang artinya memelihara dalam keadaan selamat sentosa dan berarti juga patuh dan taat. Kata Aslama menjadi pokok kata Islam, orang nya disebut muslim yang berarti bahwa orang itu

${ }^{6}$ Nurihsan, A. J. 2010. Bimbingan dan Konseling dalam Berbagai Latar Kehidupan. Bandung: PT. Revika Aditama, hlm. 10. 


\section{Al-Hikmah: Jurnal Dakwah, Volume 12, Nomor I, Tahun 2018 \\ [P. 65-82]}

menyatakan dirinya untuk taat, tunduk dan patuh kepada Allah SWT. Dengan melakukan aslama orang tersebut terjamin hidupnya selamat dunia dan akhirat ${ }^{7}$.

Dari uraian tersebut di atas, dapat disimpulkan bahwa pengetian Bimbingan dan Konseling Islam adalah proses pemberian bantuan kepada individu atau sekelompok individu dalam mengatasi atau memecahkan masalah kehidupan secara face to face atau kontak langsung dengan wawancara agar individu tersebut menyadari kembali eksistensinya sebagai makhluk Allah yang seharusnya mampu hidup selaras dengan ketentuan dan petunjuk Allah, sehingga dapat mencapai kebahagiaan hidup dunia dan akhirat ${ }^{8}$.

Menutut Anwar Sutoyo hakekat bimbingan dan konseling Islami adalah upaya membantu individu belajar mengembangkan fitrah dan atau kembali kepada fitrah dengan cara memberdayakan (enpoweering) iman, akal, dan kemauan yang dikaruniakan Allah swt kepadanya untuk mempelajari tuntunan Allah dan rasulNya, agar fitrah yang ada pada individu itu berkembang

${ }^{7}$ Razak, N. 1996. Dienul Islam. Bandung: Al - Ma'ruf., hlm. 36.

8 Afifuddin, H. 2012. Bimbingan dan Penyuluhan. Bandung: CV. Pustaka Setia, hlm. 89. dengan benar dan kokoh sesuai tuntunan Allah swt ${ }^{9}$.

2. Narsis

Istilah narcissism adalah cinta diri sendiri yang sangat ekstrem. Orang yang berprilaku narcissism cenderung menjadi sangat self counsiousness ${ }^{10}$. Dari pengertian tersebut dapat disimpulkan bahwa pada dasar nya setiap orang memiliki kecendrungan berperilaku narcissism.

Adapun yang dimaksud dengan perilaku narcissism adalah kegiatan atau tindakan individu yang diwujudkan dalam bentuk gerak dan ucapan dalam mencaintai diri sendiri secara berlebihan atau perhatian yang sangat ekstrem terhadap diri sendiri sebagai orang yang paling pandai, paling cantik, paling tampan, paling hebat dan paling segalanya. Individu yang demikian memang tidak perlu memperhatikan perasaan orang lain, dan tidak perlu memikirkan orang lain, orang yang sangat egoisentris.

Dalam kadar berbeda, kebanggaan terhadap diri sendiri dimiliki hampir oleh semua orang. Akan tetapi

9 Sutoyo, A. 2009. Bimbingan dan Konseling Islami. Semarang: Widya Karya, hlm. 23.

10 J.P.Chaplin. 2003. Kamus Lengkap Psikologi. Diterjemahkan oleh K. Kartono. Jakarta : Grafindo, hlm. 451. 
jika berlebihan, terutama kebanggaan terhadap fisik, maka dapat dikatakan bahwa perilaku tersebut sudah menjadi penyakit. Biasanya orang yang berperilaku narcissism dia merasa dirinya paling cantik atau ganteng, ia akan sulit menyukai orang lain, karena ia terlalu mencintai diri sendiri, dan sangat egoisentris sekali. Perilaku narcissism dapat dimiliki setiap orang, baik laki - laki maupun perempuan. Mereka umumnya sensitif dengan komentar negatif orang lain tentang dirinya.

a. Ciri-ciri Perilaku Narsis

Ada beberapa ciri - ciri atau tanda - tanda narcissism dari Diagnostics and Statistik Manual, Fourt Editions Text Revision antara lain:

1) Orang yang narsis merasa dirinya sangat penting dan sangat berkeinginan dikenal orang lain karena kelebihannya.

2) Pengidap narcissism juga yakin kalau dirinya unik dan istimewa, serta berpikiran bahwa tidak ada yang bisa menyaingi dirinya. Dia akan merasa lebih tinggi statusnya serta lebih cantik atau ganteng dibandingkan orang lain.
3) Orang narcissism ini selalu ingin dipuji dan diperhatikan. Mereka kurang peka terhadap kebutuhan orang lain, karena yang ada didalam pikirannya hanyalah diri sendiri.

4) Orang yang narcissism sangat sensitif terhadap kritikan, kritikaan yang kecil bisa berarti besar bagi mereka, dan tidak mau disalahkan.

5) Bangga mempertontonkan anggota tubuhnya, dan gejala yang paling jelas adalah sangat gemar bercermin.

6) Orang narcissism membutuhkan pengakuan dari orang lain, demi memopa rasa percaya dirinya.

7) Selalu ingin didahulukan oleh semua orang dalam segala hal.

8) Merasa dirinya sangat penting.

9) Adanya fantasi bahwa dia memiliki kualitas yang unik dan berbeda.

10) Merasa menjadi sangat spesial dan hanya orang yang spesial saja yang mengerti tentang dirinya.

11) Membutuhkan pengakuan dan perhatian yang lebih dari orang lain.

12) Bangga dengan gelarnya.

13) Tingkah laku yang arogan. 


\section{Al-Hikmah: Jurnal Dakwah, Volume 12, Nomor I, Tahun 2018 \\ [P. 65-82]}

Orang disebut narcissism apabila dia mempunyai lebih besar atau sama dengan lima dari karakteristik atau ciri - ciri narcissism, apabila kurang dari lima ciri - ciri tersebut maka dia masih dalam kategori kecendrungan narcissism. Adanya kecendrungan narcissism pada skala rendah dan masuk akal, itu tidak berbahaya bagi manusia tapi perlu dicegah agar tidak terindikasi kepada perilaku narcissime.

b. Faktor Penyebab Perilaku Narsis

Penyebab pasti gangguan atau perilaku narcissism tidak diketahui ${ }^{11}$. Para peneliti mengidentifikasikan faktor - faktor perkembangan masa anak - anak dan sikap orang tua yang mungkin mendukung terjadinya gangguan kepribadian narcissism anatara lain:

1) Tempramen yang sangat sensitif sejak lahir.

2) Pujian dan penilaian yang berlebihan dari orang tua.

3) Penilaian orang tua sebagai tujuan untuk mengatur harga diri mereka.
4) Sanjungan yang berlebihan yang tidak pernah seimbang dengan kenyataan timbal balik.

5) Pemberian perhatian yang tidak terduga dari orang tua.

6) Penyiksaan yang terlalu pada waktu kecil.

7) Membanggakan penampilan dan bakat orang tua.

Pada dasarnya pola asuh orang tua sebenarnya juga mempengaruhi seorang anak untuk terbentuk menjadi seseorang yang narcissism, sebagaimana sabda Rasulullah SAW:

$$
\begin{aligned}
& \text { عَنْ أَبِ هُرَيْرَة أَََّهُه كَانَ يَقُولُ قَالَ رَسُولُ اللَّهُ }
\end{aligned}
$$

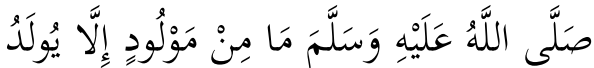

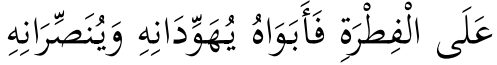

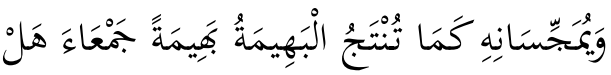

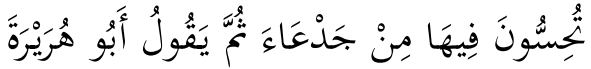

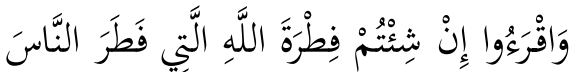

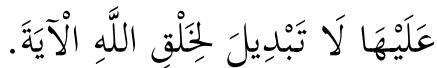

Dari Abu Hurairah RA, dia berkata, "Rasulullah SAW telah bersabda, 'Seorang bayi tidak dilahirkan \{ke dunia ini\} melainkan ia berada dalam kesucian \{fitrah\}. Kemudian kedua orang tuanyalah yang akan membuatnya menjadi Yahudi, Nasrani, ataupun Majusi ${ }^{12}$.

\footnotetext{
${ }^{11}$ Error! Main Document Only.
}

12 (Mukhtashar Shahih Muslim, rev 1.03 update 26.03.2009. Syaikh Muhammad Nashiruddin AlAlbani, HR.Muslim (8/52) no 1861). 
Jadi, apakah anak itu akan jadi seperti apa tergantung pada orang tua bagaimana mereka mengasuh dan mendidik anaknya, karena orang tua cenderung akan membentuk anak sesuai dengan pola pikir, watak, serta pengetahuan yang didapatnya. Begitu pula anak cenderung akan mengikuti serta meniru apa yang diperbuat dan diajarkan oleh orang tua. Akan tetapi tidak menutup kemungkinan lingkungan juga mempengaruhi terjadinya perilaku narcissism, sebab pengalaman kehidupan dan lingkungan akan sangat mempengaruhi cara berpikiran seseorang, yang berakibat pada terciptanya sosok manusia hasil pembentukan sosial.

c. Pandangan Islam Terhadap Perilaku Narsis

Setelah mengetahui pengertian dan karakteristik perilaku narsis sebenarnya dalam islam sudah terdapat konsep yang mirip dengan perilaku narsis seperti riya', sum 'ah dan takabur. Didalam perilaku narsis terdapat unsur riya', sum'ah dan takabur. Seperti halnya riya', dalam perilaku narcissism juga terdapat hakikat yang sama, yakni melakukan sesuatu agar mendapatkan pujian, sanjungan, penghargaan dan sebagainya dari orang lain. Lebih jelasnya, menurut $\operatorname{Hasan}^{13}$, Riya' adalah sifat suka menampilkan diri dalam beramal, agar amal tersebut dilihat orang dengan maksud ingin mendapat simpati dan pujian. Kemudian, sum'ah adalah sifat suka menceritakan amal perbuatan agar didengar orang lain dengan maksud untuk mendapatkan pujian. Sebagaimana hadits yang diriwayatkan oleh Bukhari, No hadis 6018:

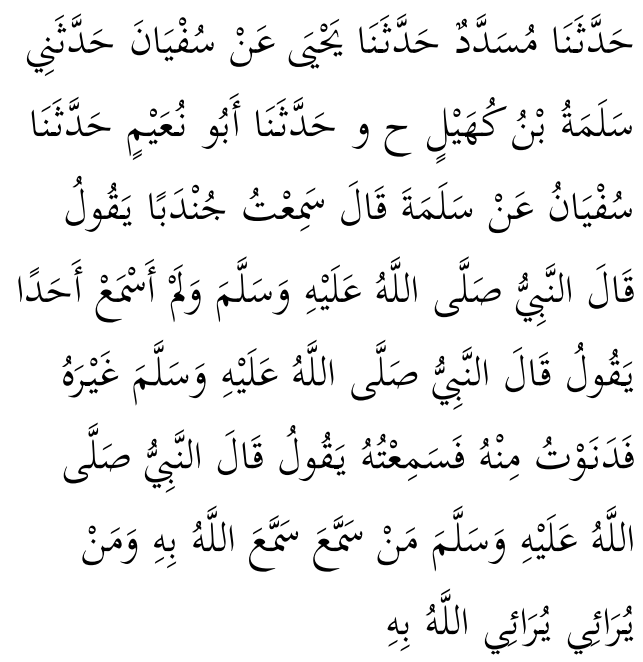

Telah menceritakan kepada kami Musaddad telah menceritakan kepada kami Yahya dari Sufyan telah menceritakan kepadaku Salamah bin Kuhail. lewat jalur periwayatan lain, telah menceritakan kepada kami Abu Nu'aim telah menceritakan kepada

13 AF, Hasan. 2012. Akidah Akhlak Madrasah Tsanawiyah Kelas VII. Semarang: PT. Karya Toha Putra, hlm. 128. 


\section{Al-Hikmah: Jurnal Dakwah, Volume 12, Nomor I, Tahun 2018 \\ [P. 65-82]}

kami Sufyan dari Salamah mengatakan; aku mendengar Jundab menuturkan, Nabi SAW bersabda, dan aku tak mendengar seorang pun (selainnya) mengatakan dengan redaksi 'Nabi shallallahu 'alaihi wasallam bersabda, maka aku dekati dia, dan kudengar dia menuturkan, Nabi shallallahu 'alaihi wasallam bersabda:

"Barangsiapa yang beramal karena sum'ah, Allah akan menjadikannya dikenal sum'ah, sebaliknya barangsiapa yang beramal karena riya', Allah akan menjadikannya dikenal riya."

Hadis di atas menjelaskan bahwa orang yang berlaku sum'ah dan riya' akan dikenal sesuai dengan apa yang ditampilkannya. Adapun orang yang riya' merupakan terrgolong kepada orang-orang yang mendustakan agama, sebagaimana dalam firman Allah SWT dalam surah Al-Ma'un ayat 1-7 :

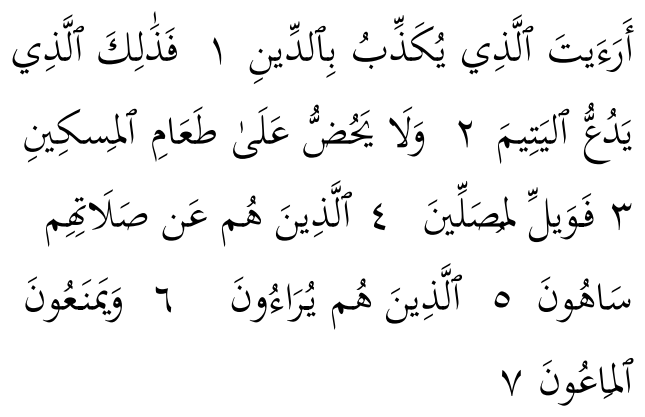

"Tahukah kamu (orang) yang mendustakan agama. Itulah orang yang menghardik anak yatim. Dan tidak menganjurkan memberi makan orang miskin. Maka kecelakaanlah bagi orang-orang yang shalat. (yaitu) orang-orang yang lalai dari shalatnya. Orang-orang yang berbuat riya. Dan enggan (menolong dengan) barang berguna".

Jelas sekali ayat Alquran di atas menyebutkan bahwa riya' merupakan termasuk perbuatan orang yang mendustakan agama, dan riya' dapat membuat pelakunya tidak diridhai Allah SWT, juga termasuk kepada golongan orang-orang yang celaka. Dapat disimpulkan bahwa hakikat narsis sama dengan riya', sum'ah yaitu sama-sama ingin mendapatkan pujian dari orang lain, agar orang lain mengetahui apa yang telah dilakukannya, membutuhkan pengakuan dari orang lain.

Selanjutnya, takabur merupakan sifat tercela yang artinya sombong. Takabur merupakan penyakit hati berupa kebanggan dan kesombongan atas nikmat yang Allah berikan. Orang yang terkena penyakit tersebut, mula-mula merasa banggga terhadap kelebihankelebihan yang dimiliki. Rasa bangga terus muncul secara berlebihan. Menurut Imam Ghazali ada 7 nikmat yang menyebabkan seseorang menjadi takabur, yaitu:

1) Ilmu pengetahuan. Tidak sedikit orang yang memiliki ilmu 
pengetahuan yang tinggi merasa

dirinya paling pandai.

2) Amal ibadah. Jika orang beribadah kurang ikhlas, bisa menyebabkan takabur apalagi kalau perbuatan ibadahnya itu menjadi perhatian orang lain.

3) Kebangsawanan.

Kebangsawanan mudah menjerumuskan seseorang menjadi takabur, sehingga memandang orang lain rendah dan kecil.

4) Kecantikan dan ketammpanan rupa. Kecantikan dan ketampanan rupa bukan saja dapat membawa seseorang kepada sifat sombong, tetapi juga suka mencela dan menyebut aib orang lain.

5) Harta dan kekayaan. Karena merasa dirinya serba kecukupan seseorang mudah menjadi takabur.

6) Kekuatan dan kekuasaan. Seseorang bisa menjadi angkuh dan sombong karena di tangannya ada kekuatan dan kekuasaan.

7) Banyak pengikut, teman sejawat, karib kerabat yang mempunyai kedudukan dan pejabat-pejabat penting $^{14}$.

\section{Metodelogi Penelitian}

Metode penelitian ini menggunakan metode penelitian tindakan kelas yang dalam bimbingan konseling disebut dengan penelitian tindakan dalam bimbingan dan konseling. Menurut Menurut Suharsimi Arikunto dalam Dede Rahmat Hidayat dan Aip Badrujaman ${ }^{15}$ pengertian penelitian tindakan dijelaskan dalam dua kata, yaitu:

a. Penelitian adalah kegiatan mencermati suatu obyek menggunakan aturan metode tertentu untuk memperoleh data atau informasi.

b. Tindakan adalah suatu gerak kegiatan yang sengaja dilakukan dengan tujuan tertentu.

Menurut Kemmis dan McTaggart dalam Dede Rahmat Hidayat dan Aip Badrujaman $^{16}$, penelitian tindakan pada hakikatnya berupa rangkaian kegiatan yang terdiri dari empat langkah, yaitu perencanaan, tindakan, pengamatan, dan refleksi. Keempat langkah tersebut

${ }^{14}$ AF, H. 2011. Akidah Akhlak Madrasah Tsanawiyah Kelas VIII. Semarang: PT. Karya Toha Putra., hlm. 69.

15 Dede Rahmat Hidayat dan Aip Badrujaman. 2012. Penelitian Tindakan dalam Bimbingan Konseling. Jakarta: PT.Indeks, hlm. 1112 .

16 Dede Rahmat Hidayat dan Aip Badrujaman. 2012. Penelitian..., hlm. 12. 


\section{Al-Hikmah: Jurnal Dakwah, Volume 12, Nomor I, Tahun 2018 \\ [P. 65-82]}

dipandang sebagai satu siklus penelitian tindakan. Dengan demikian pengertian siklus pada penelitian adalah suatu putaran kegiatan yang terdiri dari perencanaan, tindakan, pengamatan, dan refleksi.

Jadi, secara sederhana Penelitian Tindakan Bimbingan Konseling (PTBK) dapat diartikan sebagai sebuah kegiatan penelitian untuk memberikan tindakan yang dilakukan dalam lingkup kegiatan bimbingan dan konseling.

Data yang dikumpulkan pada penelitian tindakan ini adalah berupa data diskripsi tentang berperilaku kecenderungan narsis. Sumber data pada penelitian tindakan ini adalah siswa kelas XI MAN 2 Pontianak yang berjumlah 8 orang. Hal tersebut didasarkan atas pertimbangan informasi dari Guru BK bahwa mereka adalah siswa yang sering keluar masuk ruang $\mathrm{BK}$ dan sering melanggar aturan sekolah. Seperti sering terlambat dan terazia membawa handphone.

Ditambah lagi mereka merupakan siswa yang lebih terkenal dari siswa yang lain, hal tersebut terbukti dari banyak nya follower dan photo mereka di media sosial banyak yang memberikan like.

Siswa kelas XI MAN 2 Pontianak tersebut menunjukkan karakteristik berperilaku narsis, yaitu berkeyakinan bahwa dirinya istimewa, bersikap arogan, mempunyai kebutuhan untuk dipuji dan empati, mempunyai fantasi-fantasi tentang kesuksesan, dan kurang memiliki empati.

Penelitian ini dilaksanakan di MAN

2 Pontianak, di Jalan A.Yani No.9 Pontianak.

Teknik pengumpulan data pada penelitian ini adalah Observasi dan Angket (Kuesioner) Perilaku Narsis.

Tabel

Kisi - kisi Angket Perilaku Narsis

\begin{tabular}{|c|c|c|c|c|}
\hline \multirow[t]{2}{*}{ ND } & \multirow{2}{*}{ INDIKATOR } & \multicolumn{2}{|c|}{ NDMDR ITEM } & \multirow{2}{*}{$\begin{array}{l}\text { JUMLAH } \\
\text { ITEM }\end{array}$} \\
\hline & & PDSITIF & NEGATIF & \\
\hline $\mathrm{I}$. & $\begin{array}{l}\text { Keyakinan bahwa } \\
\text { dirinya "istimewa" }\end{array}$ & 13,17 & 15,18 & 4 \\
\hline 2. & $\begin{array}{l}\text { Minta dipuji secara } \\
\text { eksesif }\end{array}$ & 1,8 & 2,3 & 4 \\
\hline 3. & $\begin{array}{l}\text { Kurang memiliki } \\
\text { empati }\end{array}$ & 6.11 & 19,20 & 4 \\
\hline 4. & Bersikap arogan & 21,23 & 16,26 & 4 \\
\hline 5. & $\begin{array}{l}\text { Sering iri terhadap } \\
\text { orang lain }\end{array}$ & 30,34 & 7,25 & 4 \\
\hline 6 & $\begin{array}{l}\text { Mengeksploitasi } \\
\text { orang lain }\end{array}$ & 9, 10 & 27,32 & 4 \\
\hline 7. & $\begin{array}{c}\text { Perasaan bahwa } \\
\text { dirinya orang paling } \\
\text { penting }\end{array}$ & 5,12 & 28,31 & 4 \\
\hline 8. & $\begin{array}{c}\text { Mempunyai } \\
\text { kebutuhan untuk } \\
\text { dipuji dan empati }\end{array}$ & 24,35 & 33,36 & 4 \\
\hline 9. & $\begin{array}{l}\text { Mempunyai fantasi } \\
\text { - fantasi tentang } \\
\text { kesuksesan }\end{array}$ & 14, 22 & 4,29 & 4 \\
\hline & Jumlah & 18 & 18 & 36 \\
\hline
\end{tabular}

\section{Pembahasan}

1. Materi Bimbingan dan Konseling Islam dalam Menangani Siswa Berperilaku Kecenderungan Narsis

Sesuai dengan Rencana Pelaksanaan Layanan yang dilampirkan materi bimbingan konseling Islam 
dalam penanganan siswa berperilaku kecenderungan narsis adalah sebagai berikut:

a. Perilaku narsis dengan sub materi pengertian dan ciri - ciri perilaku narsis dengan sumber materi dari buku Psikologi Abnormal edisi ke 9 Terjemahan Fajar $\mathrm{N}$ penerbit Rajawali Press Halaman 586 pada siklus 1 pertemuan 2 dan 3 .

b. Perilaku narsis dengan sub materi dampak perilku narsis pada pertemuan 4 dan 5 .

c. Perilaku narsis dengan sub materi perilaku narsis dalam pandangan Islam dan cara terhindar dan terlepas dari perilaku narsis pada siklus 2 pertemuan 7 dan 8 .

2. Penerapan Bimbingan dan Konseling Islam dalam Penanganan Siswa Berperilaku Kecenderungan Narsis

Adapun hasil yang didapatkan setelah dilakukannya tindakan adalah sebagai berikut:

a. Siklus Pertama

1) Perencanaan

Pada saat perencanaan, peneliti membuat rencana pelaksanaan layanan yang disingkat RPL bimbingan dan konseling Islam pada siswa berperilaku kecenderungan narsis di kelas XI MAN 2 Pontinak. RPL dilampirkan.

2) Pelaksanaan

Pelaksanaan Bimbingan Konseling Islam dengan jenis layanan bimbingan konseling kelompok pada siklus pertama ini dilakukan dengan dua tahap. Tahap pertama pada pertemuan 2 dan 3 , tahap kedua pada pertemuan 4 dan 5 .

Pelaksanaan tahap pertama dilakukan agar konseli memahami perilaku narsis dan mereka menyadari bahwa mereka berperilaku kecenderungan narsis. Pelaksanaan tahap kedua layanan konseling kelompok dengan indikator pencapaian konseli dapat mengetahui dampak positif dan negatif perilaku narsis, dan menyadari bahwa perilaku narsis dapat memberi dampak negatif bagi diri.

3) Refleksi

Dari pelaksanaan Bimbingan dan konseling Islam dengan jenis layanan Konseling Kelompok masih dianggap belum berhasil, dikarenakan penurunan persentase perilaku narsis belum berada dibawah $50 \%$. Maka dari itu perlu dilaksanakan tindakan siklus kedua. 


\section{Al-Hikmah: Jurnal Dakwah, Volume 12, Nomor I, Tahun 2018 \\ [P. 65-82]}

\section{b. Siklus Kedua}

1) Perencanaan

Siklus kedua diawali dengan prosedur yang sama dengan siklus pertama dan RPL dilampirkan.

2) Pelaksanaan

Pelaksanaan Bimbingan Konseling Islam dengan jenis layanan bimbingan konseling kelompok pada siklus kedua ini dilakukan dengan 1 tahap. Melanjutkan apa yang telah dilaksanakan pada siklus pertama. Adapun tindakan siklus kedua ini dilakukan pada pertemuan 6 dan 7 .

Pelaksanaan tahap kedua dilakukan agar konseli benar - benar memahami perilaku narsis, mereka menyadari bahwa mereka berperi- laku kecenderungan narsis. Dan menghindari dari penerapan perilaku narsis di kehidupan mereka. Pelaksanaan tahap kedua layanan konseling kelompok dengan indikator pencapaian konseli dapat mengetahui perilaku narsis dalam pandangan Islam. Kemudian, memahami bahwa apapun yang berkaitan dengan narsis harus dihindari. Serta konseli sadar, dapat terhindar dan dapat terlepas dari berperilaku narsis.

Kemudian, secara rinci penurunan perilaku narsis pada masing - masing siklus dapat dilihat pada tabel berikut:

Tabel 9

Persentase Perubahan Perilaku narsis Masing - masing Siklus

\begin{tabular}{|c|c|c|c|c|}
\hline \multirow[b]{2}{*}{ №. (Konseli) } & Sebelum Tindakan & \multicolumn{2}{|c|}{ Siklus 1} & \multirow{3}{*}{$\begin{array}{c}\text { Siklus 2 } \\
\text { Pertemuan } \\
6 \text { dan } 7 \\
43 \\
(31.61 \%)\end{array}$} \\
\hline & Pertemuan I & Pertemuan 2 dan 3 & Pertemuan 4 dan 5 & \\
\hline I. (Al) & $\begin{array}{c}|3| \\
(130,77 \%)\end{array}$ & $\begin{array}{c}62 \\
(45,58 \%)\end{array}$ & $\begin{array}{c}89 \\
(65.44 \%)\end{array}$ & \\
\hline 2. (END) & $\begin{array}{c}136 \\
(94,40 \%)\end{array}$ & $\begin{array}{c}77 \\
(56,62 \%)\end{array}$ & $\begin{array}{c}75 \\
(55.15 \%)\end{array}$ & $\begin{array}{c}45 \\
(33,09 \%)\end{array}$ \\
\hline 3. (FA) & $\begin{array}{c}136 \\
(94.40 \%)\end{array}$ & $\begin{array}{c}91 \\
\text { (66,9l\%) }\end{array}$ & $\begin{array}{c}80 \\
(58,82 \%)\end{array}$ & $\begin{array}{c}47 \\
(34,55 \%)\end{array}$ \\
\hline 4. (ZFAS) & $\begin{array}{c}81 \\
(56,25 \%)\end{array}$ & $\begin{array}{c}\text { 90 } \\
(66,17 \%)\end{array}$ & $\begin{array}{c}82 \\
(60,29 \%)\end{array}$ & $\begin{array}{c}42 \\
(30,88 \%)\end{array}$ \\
\hline 5. (RM) & $\begin{array}{c}80 \\
\text { (61,II\%) }\end{array}$ & $\begin{array}{c}84 \\
(61,76 \%)\end{array}$ & $\begin{array}{c}87 \\
(63,97 \%)\end{array}$ & $\begin{array}{c}46 \\
(33,82 \%)\end{array}$ \\
\hline 6. (RKB) & $\begin{array}{c}85 \\
(59,03 \%)\end{array}$ & $\begin{array}{c}82 \\
(60,29 \%)\end{array}$ & $\begin{array}{c}82 \\
(60,29 \%)\end{array}$ & $\begin{array}{c}42 \\
(30,80 \%)\end{array}$ \\
\hline 7. (RA) & $\begin{array}{c}81 \\
(56,25 \%)\end{array}$ & $\begin{array}{c}85 \\
(62.50 \%)\end{array}$ & $\begin{array}{c}79 \\
(58,09 \%)\end{array}$ & $\begin{array}{c}44 \\
(32,35 \%)\end{array}$ \\
\hline 8. (DPS) & $\begin{array}{c}93 \\
(64.58 \%)\end{array}$ & $\begin{array}{c}89 \\
(65.44 \%)\end{array}$ & $\begin{array}{c}81 \\
(59,55 \%)\end{array}$ & $\begin{array}{c}49 \\
(36,03 \%)\end{array}$ \\
\hline
\end{tabular}




\begin{tabular}{c|c|c|c|c|} 
9. TOTAL & 831 & 660 & 665 \\
$(72,12 \%)$ & $(60,65 \%)$ & $(60,20 \%)$ & $(358,90 \%)$ \\
\hline
\end{tabular}

Berdasarkan data di atas, jika dilihat dari pertemuan sebelum tindakan sampai kepada setelah pertemuan ke 6 dan 7, terjadi penurunan persentase perilaku narsis sebesar 39,22\%. Dari persentase perilaku narsis sebesar $72,12 \%$ menjadi 32,90\%. Walaupun persentase penurunan tidak mutlak $50 \%$, namun penurunan perilaku narsis tersebut telah mencapai taraf minimal, sehingga pelaksanaan tindakan dapat dihentikan pada siklus kedua.

\section{KESIMPULAN}

Berdasarkan hasil penelitian dan pembahasan dapat disimpulkan bahwa: Materi Bimbingan dan Konseling Islam dalam penanganan siswa berperilaku kecenderungan narsis adalah sebagai berikut: Perilaku narsis dengan sub materi pengertian dan ciri - ciri perilaku narsis; Perilaku narsis dengan sub materi dampak perilku narsis; Perilaku narsis dengan sub materi perilaku narsis dalam pandangan Islam dan cara terhindar dan terlepas dari perilaku narsis. Penerapan Bimbingan dan Konseling Islam dalam penanganan siswa berperilaku kecenderungan narsis menggunakan jenis layanan konseling kelompok. Hasil yang didapatkan setelah dilakukannya Bimbingan dan Konseling Islam pada siswa berperilaku kecenderungan narsis di kelas XI MAN 2 Pontianak adalah jika dilihat dari pertemuan sebelum tindakan sampai kepada setelah pertemuan ke 6 dan 7 , terjadi penurunan persentase perilaku narsis sebesar 39,22\%. Dari persentase perilaku narsis sebesar $72,12 \%$ menjadi $32,90 \%$. Terjadi perubahan perilaku, siswa menjadi sadar penah berperilaku kecenderungan narsis dan meninggalkan perilaku kecenderungan narsis.

\section{DAFTAR PUSTAKA}

AF, H. 2011. Akidah Akhlak Madrasah Tsanawiyah Kelas VIII. Semarang: PT. Karya Toha Putra.

AF, H. 2012. Akidah Akhlak Madrasah Tsanawiyah Kelas VII. Semarang: PT. Karya Toha Putra.

Afifuddin, H. 2012. Bimbingan dan Penyuluhan. Bandung: $\mathrm{CV}$. Pustaka Setia.

Badrujaman, D. R. 2012. Penelitian Tindakan dalam Bimbingan Konseling. Jakarta: PT.Indeks.

Desmita. 2009. Psikologi Perkembangan. Bandung: PT. Remaja RosdaKarya.

Gerald C.Davidson, J. M. 2012. Abnormal Psychology edisi ke-9. Diterjemahkan oleh N. Fajar. Jakarta: Rajawali Press. 
Gunawan, Y. 2001. Pengantar Bimbingan dan Konseling. Jakarta: Prenhallindo.

Hamdani,MA. 2012. Bimbingan dan Penyuluhan.Bandung: CV.Pustaka Setia.

Hendry Ar,Eka, Rusdi Sulaiman, Abdul Mukti Ro'uf, Sumin, Ahmad Maksum,Moh Yusuf Hidayat. 2014. Pedoman Penulisan Skripsi IAIN Pontianak. Pontianak: IAIN Pontianak Press.

Ismaya, Bambang. 2015. Bimbingan \& Konseling Studi, Karier, dan Kelouarga.Bandung: Refika Aditama.

Ibrahim, 2015. Metode Penelitian Kualitatif. Bandung: Alfabeta.

J.P.Chaplin. 2003. Kamus Lengkap Psikologi. Diterjemahkan oleh K. Kartono. Jakarta : Grafindo.

Jauhar, Mohammad. 2014. Dasar - dasar Konseling. Jakarta: Prestasi Putaka.

Kartono, K. 2000. Hygine Mental. Bandung: Mandar Maju.

Kurnanto, Edi. 2013. Konseling Kelompok. Bandung: Alfabeta.

Kurnanto, Edi 2011. Langkah - langkah Penanganan Kasus Konseling. Pontianak: StainPress.

Mahmud. (2011). Metode Penelitian Pendidikan. Bandung: Pustaka Setia.

Musnamar, T. 1992. Dasar - dasar Konseptual Bimbingan dan Konseling Islam. Yogyakarta: UII Press.

Nurihsan, A. J. 2010. Bimbingan dan Konseling dalam Berbagai Latar Kehidupan. Bandung: PT. Revika Aditama.
Nurihsan, A. J. 2012. Landasan Bimbingan \& Konseling. Bandung: Rosda Karya.

Nursalim, $\quad 2015$. Pengembangan Profesi Bimbingan \& Konseling. Jakarta: Erlangga.

Razak, N. 1996. Dienul Islam. Bandung: $\mathrm{Al}$ - Ma'ruf.

Sartono, H. U. 2001. Bimbingan dan Penyuluhan. Bandung: CV. Pustaka Setia.

Shekespire, W. 2004. Romeo\&Juliet. dalam T. Sumardjo, $R M$ Palaka.Jakarta: HYENA.

Sugiyono. 2013. Metode Penelitian Kuantitatif,Kualitatif dan $R \& D$. Bandung: Alfabeta.

Sukardi. 2014. Metodologi Penelitian Pendidikan. Jakarta: Bumi Aksara.

Sutoyo, A. 2009. Bimbingan dan Konseling Islami. Semarang: Widya Karya.

Wahyuni, G. K. 2011. Teori dan Teknik Konseling. Jakarta: Pt.Indeks.

http://psikologiabnormal.wikispace.com, Faktor Penyebab Perilaku Narsis; diakses tanggal 16 Februari 2016. 
Hesty Nurrahmi

Elvya Rizki Oktaviani

Bimbingan dan Konseling Islam pada Berperilaku Kecenderungan Narsis di Kelas XI MAN 2 Pontianak 